\title{
PEMANFAATAN LIMBAH CAIR TAHU DAN PUPUK NPKMg TERHADAP PERTUMBUHAN VEGETATIF BIBIT KELAPA SAWIT (Elaeis guineensis Jacq.)
}

\author{
Boy Patianta Ginting \\ Alumnus Program Studi Budidaya Perkebunan, Fakultas Pertanian dan Peternakan, Universitas Tjut Nyak \\ Dhien, Medan 20123, Sumatera Utara, Indonesia. \\ Erfan Wahyudi* \\ Program Studi Budidaya Perkebunan, Fakultas Pertanian dan Peternakan, Universitas Tjut Nyak Dhien, \\ Medan 20123, Sumatera Utara, Indonesia. Email: erfan.wahyudi1@ gmail.com \\ Tengku Boumedine Hamid Zulkifli \\ Program Studi Agroteknologi, Fakultas Pertanian dan Peternakan, Universitas Tjut Nyak Dhien, Medan \\ 20123, Sumatera Utara, Indonesia.
}

\begin{abstract}
Abstrak
Penelitian ini bertujuan untuk mengkaji pemanfaatan limbah cair tahu dan pupuk NPKMg terhadap pertumbuhan vegetatif bibit kelapa sawit (Elaeis guineensis Jacq) di pembibitan awal. Penelitian dilaksanakan di Desa Karang Rejo Kecamatan Medan Polonia, Medan. Penelitian dilaksanakan pada Juni sampai September 2015. Metode yang digunakan dalam penelitian ini adalah Rancangan Acak Kelompok (RAK) faktorial terdiri dari dua faktor. Faktor pertama: pemberian pupuk NPKMg dengan 3 taraf : $\mathrm{P}_{0}=$ tanpa pupuk NPKMg, $\mathrm{P}_{1}=$ pupuk NPKMg $2 \mathrm{~g} /$ polibag, $\mathrm{P}_{2}=$ pupuk $\mathrm{NPKMg} 4 \mathrm{~g} /$ polibag, $\mathrm{P}_{3}=$ pupuk NPKMg $6 \mathrm{~g} /$ polibag. Faktor kedua: pemberian limbah cair tahu 4 taraf: $\mathrm{L}_{0}=\operatorname{tanpa}$ limbah cair tahu, $\mathrm{L}_{1}=$ limbah cair tahu $80 \mathrm{ml} /$ polibag, $\mathrm{L}_{2}=$ limbah cair tahu $160 \mathrm{ml} / \mathrm{polibag}, \mathrm{L}_{3}=$ limbah cair tahu 240 $\mathrm{ml} /$ polibag. Peubah yang diamati: tinggi tanaman $(\mathrm{cm})$, luas daun $(\mathrm{cm} 2)$, berat basah tanaman $(\mathrm{g})$, berat kering tanaman (g). Hasil penelitian menunjukkan pemberian pupuk NPKMg menunjukkan berpengaruh nyata pada tinggi tanaman, luas daun, berat basah dan berat kering tanaman. Pemberian limbah cair tahu dan interaksinya berpengaruh tidak nyata pada semua peubah amatan dalam penelitian ini.
\end{abstract}

Kata Kunci: kelapa sawit, limbah cair tahu, pembibitan awal, pupuk NPKMg

\section{PENDAHULUAN}

Kelapa sawit adalah tanaman penghasil minyak paling tinggi produktivitasnya. Dari kelapa sawit bukan hanya diperoleh minyak untuk keperluan pangan tetapi dapat dibuat untuk keperluan industri lainnya. Keunggulan kelapa sawit cukup banyak, biaya produksi murah, produksi/ha tinggi (4-6 ton minyak/ha/tahun) dan umur ekonomi panjang (25-30 tahun) (Lubis, 1992). Menurut Chan \& Tobing, (1982) untuk mendapatkan pertumbuhan bibit yang baik diperlukan pemeliharaan di pembibitan dengan sempurna, pemberian pupuk yang tepat merupakan faktor penting. Pada masa sekarang, kebutuhan akan unsur unsur hara bagi bibit kelapa sawit belum seluruhnya diketahui. Penambahan suatu unsur hara dilakukan jika kelihatan adanya kekahatan.Aplikasi pupuk dengan efisiensi tinggi dapat diperoleh melalui peningkatan daya dukung tanah dan peningkatan ketersediaan unsur hara pupuk dalam media tanam bibit (Lubis, 1992).

Berdasarkan penelitian di Sumatera Utara, unsur-unsur hara yang berpengaruh positif terhadap pertumbuhan dan produksi kelapa sawit adalah nitrogen $(\mathrm{N})$, fosfor $(\mathrm{P})$, kalium $(\mathrm{K})$, magnesium $(\mathrm{Mg})$, serta unsur hara mikro boron (B) (Sastrosayono, 2008). Pupuk $\mathrm{NPKMg}$ merupakan hara penting bagi tanaman. Nitrogen merupakan unsur hara utama bagi pertumbuhan tanaman, pada umumnya sangat diperlukan untuk pembentukan atau pertumbuhan bagian-bagian vegetatif tanaman seperti daun, batang dan akar. Nitrogen merupakan komponen penyusun dari banyak senyawa esensial bagi tumbuhan, misalnya asam asam amino. Karena setiap molekul protein tersusun dari asam-asam amino dan setiap enzim adalah protein maka nitrogen merupakan unsur penyusun protein dan enzim. Fosfor berperan dalam berbagai proses fisiologis di dalam tanaman seperti fotosintesis dan respirasi dan sangat membantu perkembangan perakaran dan mengatur pembungaan. Kalium berperan dalam aktivitas berbagai ensim yang esensial dalam reaksi-reaksi fotosintesis dan respirasi serta untuk ensim yang terkait dalam sintesis protein dan pati (Lakitan, 2004). Pemberian pupuk NPK diberikan sebanyak $2,5 \mathrm{~g} / \mathrm{bibit}$ dan diberikan pada umur 2 minggu (Lubis, 1992). Menurut rekomendasi Pusat Penelitian Kelapa Sawit Medan, pemupukan bibit di pre nursery dapat menggunakan pupuk NPKMg (15:15:6:4) sebanyak 2,5 g/bibit melalui media tanam (PPKS, 2001).

Mengingat perannya tanaman kelapa sawit sebagai tanaman perkebunan yang sangat penting serta prioritas utama dari pemerintah serta masyarakat Indonesia umumnya dan limbah cair tahu merupakan salah satu contoh pupuk organik cair yang diharapkan dapat digunakan sebagai pupuk alternatif untuk meningkatkan pertumbuhan bibit kelapa sawit. Dengan demikian dilakukan penelitian yang bertujuan untuk mengetahui bahwa pemanfaatan limbah cair tahu dan pupuk NPKMg dapat meningkatkan pertumbuhan vegetatif bibit kelapa sawit (Elaeis guineensis Jacq) di 
pembibitan awal dan untuk mengetahui bahwa limbah cair tahu dapat menjadi pupuk alternatif selain dari pupuk anorganik.

\section{METODE}

\section{Tempat dan Waktu Penelitian}

Penelitian ini dilaksanakan di Desa Karang Rejo Kecamatan Medan Polonia, Medan pada Juni sampai September 2015

\section{Bahan dan Alat}

Adapun bahan yang digunakan antara lain tanah yang digunakan dalam penelitian ini adalah media tanah topsoil, baby polibag $10 \mathrm{~kg}$ ukuran lebar $25 \mathrm{~cm}$ ketebalan $0,15 \mathrm{~mm}$, benih tanaman kelapa sawit D x P keluaran Marihat Siantar, pupuk NPKMg dan Limbah cair tahu, insektisida decis, herbisida roundup, fungisida dithane M45. Alat-alat yang digunakan antara lain: cangkul, gembor, label nama, alat tulis, plastik, ember, meteran, kalkulator, pompa air.

\section{Model Rancangan}

Penelitian dilakukan menggunakan Rancangan Acak Kelompok (RAK) faktorial dengan dua taraf yaitu: Faktor pertama: pemberian pupuk NPKMg dengan 3 taraf: $\mathrm{P}_{0}=$ tanpa pupuk NPKMg; $\mathrm{P}_{1}=2 \mathrm{~g} /$ polibag; $\mathrm{P}_{2}=4$ g/polibag; dan $\mathrm{P}_{3}=6 \mathrm{~g} /$ polibag. Faktor kedua: pemberian limbah cair tahu 4 taraf: $\mathrm{L}_{0}=$ tanpa limbah cair tahu; $\mathrm{L}_{1}=$ $80 \mathrm{ml} /$ polibag; $\mathrm{L}_{2}=160 \mathrm{ml} /$ polibag; dan $\mathrm{L}_{3}=240$ $\mathrm{ml} /$ polibag. Data hasil pengamatan dianalisis dengan uji F, apabila dalam uji statistik data diperoleh signifikan maka pengujian dilanjutkan dengan uji DMRT (Duncan Multiple Range Test).

\section{Persiapan Media}

Media tanam yang digunakan adalah topsoil kemudian diayak dan dibersihkan dari sisa-sisa tumbuhan dan kotoran lainnya. Kemudian dimasukkan ke baby polibag $10 \mathrm{~kg}$ ukuran lebar $25 \mathrm{~cm}$ dan tebal $0,15 \mathrm{~mm}$.

\section{Persiapan Lahan}

Lahan areal penelitian dibersihkan dari gulma dan tanaman lain yang tumbuh diatasnya kemudian lahan diolah dengan traktor dan dicangkul sampai siap tanam, kemudian dibuat petak-petak percobaan berukuran $90 \mathrm{~cm}$ x $60 \mathrm{~cm}$. Lahan penelitian dibuat naungan kemudian diatur sedemikian rupa sesuai dengan perlakuan. Setiap percobaan dalam satu plot dibatasi oleh parit drainase selebar $50 \mathrm{~cm}$, sedangkan jarak antar ulangan $100 \mathrm{~cm}$.

\section{Penanaman Kecambah}

Kecambah yang telah tumbuh diarea perkecambahan kemudian ditanam pada lubang yang telah disiapkan dipolibag yang telah terisi media tanah topsoil lahan. Kemudian tanah disekilingnya dipadatkan agar batang kecambah dapat berdiri tegak.

\section{Pemberian Pupuk NPKMg}

Pupuk yang diberikan adalah pupuk NPKMg yang sesuai dengan perlakuan. Pemberian pupuk diberikan ketika tanaman berumur 4 dan 7 Minggu Setelah Tanam (MST).

\section{Pemberian Limbah Cair Tahu}

Pemberian limbah cair tahu dilakukan sesuai dengan perlakuan. Pemberian limbah cair tahu diberikan ketika tanaman berumur 4 dan 7 Minggu Setelah Tanam (MST)..

\section{Analisis Karakteristik Limbah Cair Tahu}

Diambil air limbah tahu untuk dianalisis beberapa karaktertistik kimianya. Hasil analisis limbah cair tahu menunjukkan bahwa $\mathrm{N}$-total $0,43 \% ; \mathrm{P}_{2} \mathrm{O}_{5}$ sebesar $0,67 \%$; $\mathrm{C} / \mathrm{N}$ sebesar 12,81; C-organik sebesar 5,51\%; $\mathrm{K}_{2} \mathrm{O}$ sebesar 0,11\%; dan $\mathrm{CaO}$ sebesar 0,38\%.

\section{Peubah Amatan}

Tinggi tanaman diukur mulai dari permukaan tanah (patok standar) sampai daun tertinggi yaitu yang tegak alami. Pengukuran dilakukan pada 3 tanaman sampel mulai saat tanaman berumur 5, 7, 9, dan 11 MST. Pengukuran luas daun dilakukan menggunakan alat leaf area meter dan dilaksanakan saat tanaman berumur 5, 7, 9, dan 11 MST. Penimbangan berat basah tanaman dilakukan pada akhir penelitian. Penimbangan ini dilaksanakan pada umur 11 MST. Berat kering diamati dengan menimbang tanaman yang terlebih dahulu dikeringanginkan, kemudian dimasukkan ke dalam oven selama $3 \times 24$ jam pada suhu $65^{\circ} \mathrm{C}$. Penimbangan ini dilaksanakan pada umur $11 \mathrm{MST}$.

\section{HASIL DAN PEMBAHASAN \\ Tinggi Bibit Kelapa Sawit (cm)}

Hasil analisis pengamatan dan analisis sidik ragam dapat dilihat bahwa pemberian pupuk NPKMg menunjukkan berpengaruh tidak nyata pada umur 5 dan 11 MST, namun berpengaruh sangat nyata terhadap tinggi bibit kelapa sawit pada umur 7 dan 9 MST. Pemberian limbah cair tahu dan interaksinya berpengaruh tidak nyata terhadap tinggi tanaman kelapa sawit pada umur 5, 7, 9 dan 11 MST (Tabel 1).

Tabel 1. Pengaruh limbah cair tahu, pupuk NPKMg dan interaksinya terhadap tinggi bibit kelapa sawit pada umur 7 dan 9 MST.

\begin{tabular}{cccccc}
\hline Perlakuan & $\mathrm{P}_{0}$ & $\mathrm{P}_{1}$ & $\mathrm{P}_{2}$ & $\mathrm{P}_{3}$ & Rataan \\
\hline \multicolumn{6}{c}{7 Minggu Setelah Tanam } \\
$\mathrm{L}_{0}$ & 14,62 & 15,37 & 15,37 & 14,62 & 14,99 \\
$\mathrm{~L}_{1}$ & 14,57 & 14,62 & 15,37 & 15,37 & 14,98 \\
$\mathrm{~L}_{2}$ & 14,70 & 14,62 & 16,90 & 14,62 & 15,21 \\
$\mathrm{~L}_{3}$ & 14,80 & 14,03 & 14,80 & 14,87 & 14,63 \\
\hline Rataan & $14,67 \mathrm{~b}$ & $14,66 \mathrm{~b}$ & $15,61 \mathrm{a}$ & $14,87 \mathrm{~b}$ \\
\hline \multicolumn{6}{c}{9 Minggu Setelah Tanam } \\
$\mathrm{L}_{0}$ & 18,17 & 18,60 & 19,67 & 18,30 & 18,68 \\
$\mathrm{~L}_{1}$ & 17,67 & 18,60 & 18,47 & 18,67 & 18,35 \\
$\mathrm{~L}_{2}$ & 17,63 & 18,80 & 20,20 & 18,77 & 18,85 \\
$\mathrm{~L}_{3}$ & 17,80 & 17,37 & 18,23 & 18,40 & 17,95 \\
\hline Rataan & $17,82 \mathrm{c}$ & $18,34 \mathrm{~b}$ & $19,14 \mathrm{a}$ & $18,53 \mathrm{~b}$ \\
\hline Keteran
\end{tabular}

Keterangan: angka yang diikuti oleh huruf yang sama pada baris dan kolom yang sama menujukkan berbeda tidak nyata pada DMRT taraf 5\%. KK (7 MST) $=5,96 \%$; $\mathrm{KK}(9 \mathrm{MST})=5,24 \%$.

Tabel 1 dapat dilihat bahwa pemberian pupuk NPKMg signifikan meningkatkan tinggi bibit tanaman kelapa sawit tertinggi pada umur 7 dan 9 MST terdapat pada perlakuan $\mathrm{P}_{2}$ (4 g/polibag) masing-masing 15,61 dan 
19,14 cm. Meskipun pemberian limbah cair tahu berpengaruh tidak nyata, perlakuan $\mathrm{L}_{2}(160 \mathrm{ml} /$ polibag $)$ menunjukkan tinggi bibit tanaman kelapa sawit tertinggi pada umur 7 dan 9 MST masing-masing 15,21 dan 18,85 $\mathrm{cm}$. Interaksi juga berpengaruh tidak nyata, namun interaksi $\mathrm{P}_{2} \mathrm{~L}_{2}$ menunjukkan tinggi bibit tanaman kelapa sawit tertinggi pada umur 7 dan 9 MST masing-masing 16,90 dan $20,20 \mathrm{~cm}$.

Analisis regresi pengaruh pemberian pupuk NPKMg terhadap tinggi tanaman kelapa sawit pada umur 7 dan 9 MST dapat dilihat pada Gambar 1.
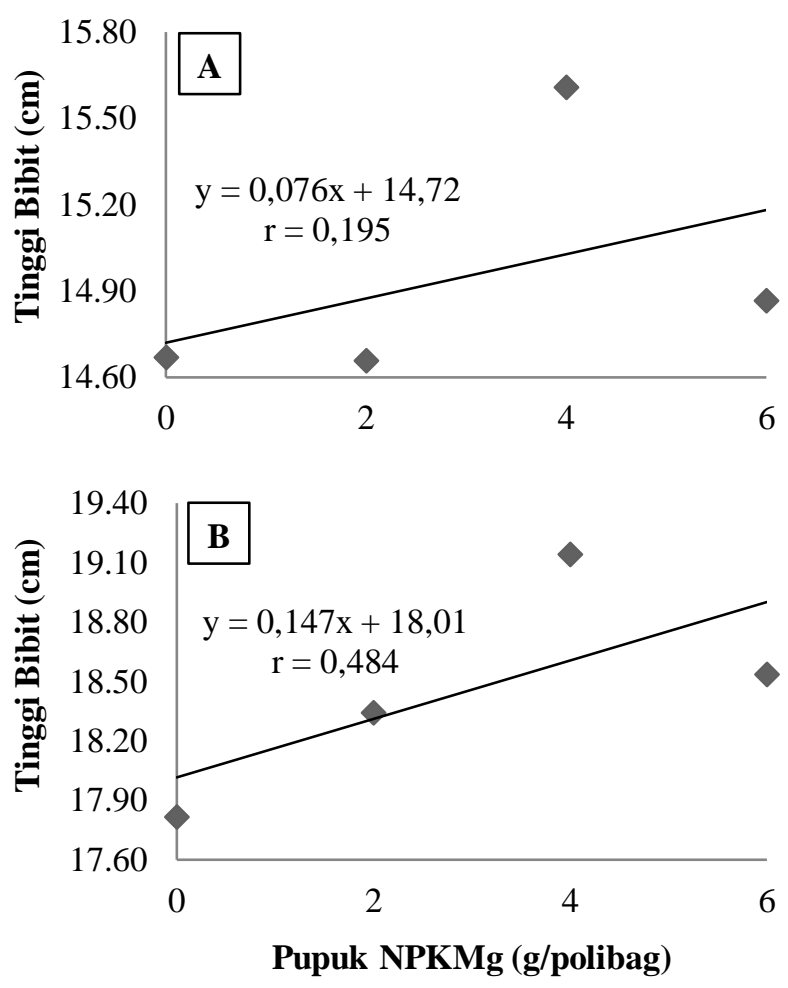

Gambar 1. Pengaruh pemberian pupuk NPKMg terhadap tinggi bibit tanaman kelapa sawit. $\mathrm{A}=7 \mathrm{MST}$ $\mathrm{B}=9 \mathrm{MST}$.

Gambar 1 dapat dilihat bahwa analisis regresi pemberian pupuk NPKMg terhadap tinggi tanaman kelapa sawit diperoleh kurva regresi linier positif dengan persamaan $\hat{Y}=0,076 x+14,72$ dengan $r=0,195$ pada umur 7 MST dan $\hat{Y}=0,147 x+18,01$ dengan $r=0,484$ pada umur 9 MST.

\section{Luas Daun $\left(\mathrm{cm}^{2}\right)$}

Hasil analisis pengamatan dan analisis sidik ragam dapat dilihat bahwa pemberian pupuk NPKMg menunjukkan berpengaruh tidak nyata pada umur 5 dan 11 MST, namun berpengaruh sangat nyata terhadap luas daun bibit kelapa sawit pada umur 7 dan 9 MST. Pemberian limbah cair tahu dan interaksinya berpengaruh tidak nyata terhadap luas daun bibit tanaman kelapa sawit pada umur 5, 7, 9 dan 11 MST (Tabel 2).

Tabel 2 dapat dilihat bahwa pemberian pupuk NPKMg signifikan meningkatkan luas daun bibit tanaman kelapa sawit tertinggi pada umur 7 dan 9 MST terdapat pada perlakuan $\mathrm{P}_{3}$ (6 g/polibag) masing-masing 37,89 dan $60,04 \mathrm{~cm}^{2}$. Meskipun pemberian limbah cair tahu berpengaruh tidak nyata, perlakuan $\mathrm{L}_{1} \quad(80$ $\mathrm{ml} /$ polibag) dan $\mathrm{L}_{3}(240 \mathrm{ml} /$ polibag $)$ menunjukkan luas daun bibit tanaman kelapa sawit tertinggi pada umur 7 dan 9 MST masing-masing 34,98 dan $58,28 \mathrm{~cm}^{2}$. Interaksi juga berpengaruh tidak nyata, namun interaksi $\mathrm{P}_{2} \mathrm{~L}_{2}$ menunjukkan luas daun bibit tanaman kelapa sawit tertinggi pada umur 7 dan 9 MST masing-masing 45,64 dan $64,22 \mathrm{~cm}^{2}$.

Tabel 2. Pengaruh limbah cair tahu, pupuk NPKMg dan interaksinya terhadap luas daun bibit kelapa sawit pada umur 7 dan 9 MST.

\begin{tabular}{cccccc}
\hline Perlakuan & $\mathrm{P}_{0}$ & $\mathrm{P}_{1}$ & $\mathrm{P}_{2}$ & $\mathrm{P}_{3}$ & Rataan \\
\hline \multicolumn{5}{c}{7 Minggu Setelah Tanam } \\
$\mathrm{L}_{0}$ & 27,37 & 30,31 & 32,69 & 41,50 & 32,97 \\
$\mathrm{~L}_{1}$ & 30,13 & 38,76 & 31,65 & 39,37 & 34,98 \\
$\mathrm{~L}_{2}$ & 25,69 & 33,10 & 45,64 & 33,89 & 34,58 \\
$\mathrm{~L}_{3}$ & 27,14 & 26,09 & 30,14 & 36,81 & 30,05 \\
\hline Rataan & $27,58 \mathrm{c}$ & $32,07 \mathrm{~b}$ & $35,03 \mathrm{ab}$ & $37,89 \mathrm{a}$ \\
\hline \multicolumn{5}{c}{9 Minggu Setelah Tanam } \\
$\mathrm{L}_{0}$ & 54,39 & 55,25 & 55,20 & 62,05 & 56,72 \\
$\mathrm{~L}_{1}$ & 55,85 & 53,11 & 55,85 & 57,69 & 55,63 \\
$\mathrm{~L}_{2}$ & 53,33 & 50,09 & 64,22 & 60,21 & 56,96 \\
$\mathrm{~L}_{3}$ & 55,18 & 57,69 & 60,05 & 60,21 & 58,28 \\
\hline Rataan & $54,69 \mathrm{c}$ & $54,04 \mathrm{c}$ & $58,83 \mathrm{ab}$ & $60,04 \mathrm{a}$ \\
\hline
\end{tabular}

Keterangan: angka yang diikuti oleh huruf yang sama pada baris dan kolom yang sama menujukkan berbeda tidak nyata pada DMRT taraf 5\%. KK (7 MST $)=22,69 \%$; $\mathrm{KK}(9 \mathrm{MST})=10,48 \%$.

Analisis regresi pengaruh pemberian pupuk NPKMg terhadap luas daun tanaman kelapa sawit pada umur 7 dan 9 MST dapat dilihat pada Gambar 2.
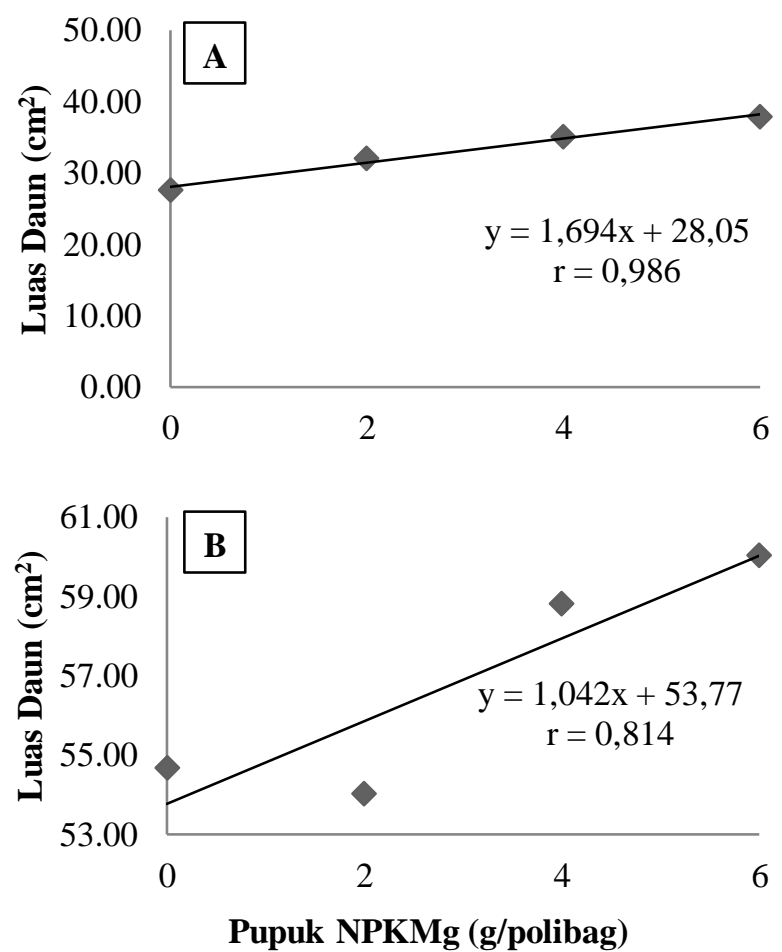

Gambar 2. Pengaruh pemberian pupuk NPKMg terhadap luas daun bibit tanaman kelapa sawit. $A=7$ MST; B= 9 MST

Gambar 2 dapat dilihat bahwa analisis regresi pemberian pupuk NPKMg terhadap luas daun tanaman kelapa sawit diperoleh kurva regresi linier positif dengan 
persamaan $\hat{Y}=1,694 x+28,05$ dengan $r=0,986$ pada umur 7 MST dan $\hat{Y}=1,042 x+53,77$ dengan $r=0,814$ pada umur 9 MST.

\section{Bobot Basah (g)}

Hasil sidik ragam menunjukkan bahwa pemberian limbah cair tahu, pupuk NPKMg dan interaksinya berpengaruh tidak nyata terhadap bobot basah bibit kelapa sawit umur 11 MST (Tabel 3).

Tabel 3. Pengaruh limbah cair tahu, pupuk NPKMg dan interaksinya terhadap bobot basah bibit kelapa sawit pada umur $11 \mathrm{MST}$.

\begin{tabular}{cccccc}
\hline Perlakuan & $\mathrm{P}_{0}$ & $\mathrm{P}_{1}$ & $\mathrm{P}_{2}$ & $\mathrm{P}_{3}$ & Rataan \\
\hline $\mathrm{L}_{0}$ & 8,36 & 7,30 & 8,48 & 8,59 & 8,18 \\
$\mathrm{~L}_{1}$ & 6,33 & 8,57 & 9,20 & 8,02 & 8,03 \\
$\mathrm{~L}_{2}$ & 7,76 & 7,76 & 9,63 & 8,02 & 8,29 \\
$\mathrm{~L}_{3}$ & 7,05 & 8,48 & 7,76 & 7,85 & 7,79 \\
\hline Rataan & 7,37 & 8,03 & 8,77 & 8,12 & \\
\hline
\end{tabular}

Keterangan: angka yang diikuti oleh huruf yang sama pada baris dan kolom yang sama menujukkan berbeda tidak nyata pada DMRT taraf $5 \%$. KK= 23,30\%.

Tabel 3 dapat dilihat bahwa pemberian pupuk NPKMg memiliki berat basah (g) tanaman pada perlakuan $\mathrm{P}_{2} \mathrm{~L}_{2}$ tertinggi yaitu $9.63 \mathrm{~g}$, berbeda tidak nyata dengan perlakuan $\mathrm{P}_{2}$ dan $\mathrm{P}_{0}$, serta $\mathrm{P}_{1}$ dan $\mathrm{P}_{3}$.

\section{Bobot Kering (g)}

Hasil sidik ragam menunjukkan bahwa pemberian limbah cair tahu, pupuk NPKMg dan interaksinya berpengaruh tidak nyata terhadap bobot kering bibit kelapa sawit umur 11 MST (Tabel 4).

Tabel 4. Pengaruh limbah cair tahu, pupuk NPKMg dan interaksinya terhadap bobot kering bibit kelapa sawit pada umur $11 \mathrm{MST}$.

\begin{tabular}{cccccc}
\hline Perlakuan & $\mathrm{P}_{0}$ & $\mathrm{P}_{1}$ & $\mathrm{P}_{2}$ & $\mathrm{P}_{3}$ & Rataan \\
\hline $\mathrm{L}_{0}$ & 2,20 & 2,15 & 2,23 & 2,36 & 2,23 \\
$\mathrm{~L}_{1}$ & 2,01 & 2,37 & 2,53 & 2,22 & 2,28 \\
$\mathrm{~L}_{2}$ & 2,16 & 2,16 & 2,65 & 2,22 & 2,30 \\
$\mathrm{~L}_{3}$ & 2,08 & 2,46 & 2,16 & 2,07 & 2,19 \\
\hline Rataan & 2,11 & 2,28 & 2,39 & 2,22 & \\
\hline
\end{tabular}

Keterangan: angka yang diikuti oleh huruf yang sama pada baris dan kolom yang sama menujukkan berbeda tidak nyata pada DMRT taraf $5 \%$. KK=16,85\%.

Pada Tabel 4 dapat dilihat bahwa pemberian pupuk NPKMg memiliki berat kering (g) tanaman pada perlakuan $\mathrm{P}_{2} \mathrm{~L}_{2}$ tertinggi yaitu $2,65 \mathrm{~g}$, berbeda tidak nyata dengan perlakuan $\mathrm{P}_{2}$ dan $\mathrm{P}_{0}$, serta $\mathrm{P}_{1}$ dan $\mathrm{P}_{3}$.

\section{Pengaruh limbah cair tahu terhadap pertumbuhan bibit tanaman kelapa sawit di pembibitan awal}

Pemberian limbah cair tahu belum mampu meningkatkan pertumbuhan bibit tanaman kelapa sawit di pembibitan awal, hal ini dapat dilihat pada hasil penelitian pada parameter peubah amatan. Pada semua parameter peubah amatan pemberian limbah cair tahu tidak nyata pada tinggi tanaman, luas daun, berat basah dan berat kering. Ini disebabkan karena kandungan hara terutama $\mathrm{N}$ atau $\mathrm{C} / \mathrm{N}$ pada limbah cair tahu sangat sedikit atau rendah sekali ini dapat dilihat pada analisis laboratorium, sedangkan pada analisis tanah sebelum tanam atau sesudah tanam hara $\mathrm{C}$ organik atau $\mathrm{C} / \mathrm{N}$ sangat sedikit sekali. Pemberian limbah cair tahu tidak dapat menambah unsur hara pada tanah sehingga akar tidak dapat menyerap dengan baik. Perkembangan sistem perkembangan yang baik sangat menentukan pertumbuhan vegetatif tanaman yang pada akhirnya menentukan fase reproduktif dan hasil tanaman. Pertumbuhan vegetatif yang baik akan menunjang fase generatif yang baik pula. Pori tanah yang lebih besar akan meningkatkan perkembangan akar dan kemampuan akar menyerap air dan unsur hara pada akarnya akan dapat mempengaruhi pertumbuhan dan serta hasil tanaman (Sumpena, 2001).

Menurut Syarif, (1986) mengemukakan bahwa untuk tanaman tahunan, penambahan jumlah daun dan luas daun membutuhkan unsur hara yang seimbang dan berlanjut dalam waktu yang cukup lama. Pada tanaman tahunan atau tanaman berumur panjang lamanya daun untuk membuka sempurna setelah keluar dari tunasnya membutuhkan waktu kira-kira satu bulan. Jumlah daun yang terbentuk dipengaruhi oleh tinggi tanaman, dimana semakin tinggi tanaman maka jumlah yang muncul akan semakin bertambah karena adanya tunas-tunas baru yang akhirnya tunas ini berkembang menjadi daun. Hal ini sesuai dengan pendapat Setyamidjaja, (1986) menyatakan bahwa semakin tinggi suatu tanaman maka jumlah daun yang muncul semakin bertambah pula sehingga dapat meningkatkan proses fotosintesis yang dapat menyimpan karbohidrat serta gula di dalam daun yang dapat dimanfaatkan oleh daun untuk proses pembelahan dan perpanjangan sel. Sutedjo, (2002) mengemukakan bahwa unsur hara nitrogen sangat dibutuhkan untuk pertumbuhan bagian-bagian vegetatif tanaman seperti akar, batang dan daun, dan apabila ketersediaannya tidak cukup dapat menghambat pertumbuhan dan perkembangan tanaman. Penambahan nitrogen yang cukup pada tanaman akan mempercepat laju pembelahan dan pemanjangan sel, pertumbuhan akar, batang dan daun berlangsung secara cepat (Setyati, 2008).

Hasil penelitian ini sejalan dengan penelitian Anggraini et al., (2018) bahwa pemberian limbah cair tahu tidak berpengaruh terhadap tinggi tanaman, jumlah daun, diameter batang, berat segar tanaman, berat kering tanaman, berat segar akar, berat kering akar pada bibit tanaman kelapa sawit di pre nursery pada umur 5 dan 12 MST. Fahlei et al., (2017) melaporkan bahwa konsentrasi limbah cair belum dapat memberikan pengaruh yang baik terhadap pertumbuhan bibit kelapa sawit di pre nursery. Tetapi penelitian ini berbeda dengan penelitian Purnomo et al., (2017) menyatakan bahwa konsentrasi limbah cair pabrik tahu $20 \mathrm{ml}$ sudah mampu menghasilkan pertumbuhan bibit yang sama baiknya dengan pupuk NPK.

\section{Pengaruh pupuk NPKMg terhadap pertumbuhan bibit tanaman kelapa sawit di pembibitan awal}

Pada penelitian ini pemberian pupuk NPKMg dapat meningkatkan pertumbuhan tanaman kelapa sawit di pembibitan awal awal. Ini dapat dilihat pada parameter pengamatan tinggi tanaman dan luas daun tanaman kelapa 
sawit. Pemberian pupuk NPKMg dapat diserap dengan baik oleh tanaman kelapa sawit yaitu unsur hara $\mathrm{N}$ yang lebih cepat terserap untuk membantu proses pertumbuhan vegetatife. Selain itu pupuk NPKMg merupakan pupuk majemuk yang mengandung lebih dari satu jenis unsur hara antara lain, unsur nitrogen, fosfos, dan kalium serta $\mathrm{Mg}$. Kandungannya yaitu $15 \% \mathrm{~N}, 15 \% \mathrm{P}_{2} \mathrm{O}_{5}$, dan $6 \%$ $\mathrm{K}_{2} \mathrm{O}$ serta $\mathrm{Mg} 4 \%$ yang masing-masing unsur hara tersebut saling mempengaruhi perkembangan dan produksi tanaman. Hal ini sesuai dengan pernyatan Harianto, (2006) bahwa K berperan penting dalam fotosintesis karena secara langsung meningkatkan pertumbuhan dan juga meningkatkan asimilasi $\mathrm{CO}_{2}$ serta meningkatkan translokasi hasil fotosintesa. Fotosintesa berjalan dengan baik, fotosintat yang terbentuk menjadi banyak kemudian di transfer keseluruh bagian tanaman untuk menunjang pertumbuhan tanaman.

Musnamar, (2006) menjelaskan bahwa satu tanaman akan tumbuh dengan suburnya, apabila segala hara yang dibutuhkan tanaman cukup tersedia, dan lagi pula hara itu adaa dalam bentuk yang sesuai untuk diserap tanaman. Suwardjono, (2003) unsur hara makro $\mathrm{N}, \mathrm{P}, \mathrm{K}, \mathrm{Ca}, \mathrm{Mg}, \mathrm{S}$ yang terdapat dalam pupuk NPK mempunyai peranan yang penting terhadap pertumbuhan vegetatif dan generatif tanaman. Nitrogen yang diserap dalam bentuk $\mathrm{NO}_{3}^{-}$direduksi dalam tanaman dan bergabung dengan senyawa organik menjadi asam amino yang kemudian membentuk protein yang menjadi subtrat dalam pembentukan dan pembelahan sel. Sebagai hara penghasil energi, $\mathrm{P}$ diserap tanaman dalam bentuk $\mathrm{H}_{2} \mathrm{PO}_{4}^{-}$dan dibutuhkan tanaman untuk pembentukan molekul pembawa enargi (ATP) pada proses metabolisme tanaman, baik pada proses fotosintesis maupun respirasi tanaman. $\mathrm{P}$ juga merupakan bagian dari membran sel, nukleotida, koenzim dan membentuk kompleks dengan gula. Dalam fase generatif (produksi tanaman), $\mathrm{P}$ juga merupakan komponen dari asam fitrat sebagai cadangan $\mathrm{P}$ dalam biji, yaitu $\mathrm{C}_{6} \mathrm{H}_{6}\left(\mathrm{H}_{2} \mathrm{PO}_{4}^{-}\right)_{6}$. Unsur $\mathrm{K}$ berpengaruh langsung terhadaap metabolisme tanaman, karena merupakan activator enzim-enzim. Magnesium merupakan komponen terpenting dalam pembentukan senyawa klorofil, bahkan setiap molekul klorofil mengandung 1 atom $\mathrm{Mg}$, sehingga keberadaan Mg sangat mempengaruhi efektivitas metabolisme khususnya pada proses fotosintesis (Balai Pengkajian Teknologi Pangan, 2004). Menurut Triharso, (1994) apabila suatu tanaman kekurangan unsur $\mathrm{N}$ akan mengakibatkan daun tanaman berwarna hijau pucat, ukuran daun kecil, Bila kekurangan $\mathrm{P}$ tanaman akan menjadi kerdil dan cepat gugur bahkan terkadang daun berwarna merah tua, serta bila tanaman kekurangan unsur $\mathrm{K}$ akan mengakibatkan keruskan pada daun tua dibagian pinggir.

\section{Interaksi pupuk urea dan urine sapi terhadap pertumbuhan bibit tanaman kelapa sawit di pembibitan awal}

Pada penelitian initidak terjadi Interaksi antara pemberian limbah cair tahu dan pupuk NPKMg pada semua parameter peubah amatan. Adanya pengaruh yang tidak nyata terhadap parameter yang diamati tersebut, hal ini menunjukkan bahwa tidak adanya interaksi disebabkan karena keduanya tidak dapat saling mempengaruhi satu sama lainnya. Sutedjo, (2002) menyatakan bahwa bila salah satu faktor lebih kuat pengaruhnya, maka masingmasing faktor mempunyai sifat dan cara kerja yang berbeda akan menghasilkan hubungan yang nyata untuk mendukung suatu pertumbuhan tanaman.

Hal lain yang menyebabkan adanya pengaruh yang tidak nyata terhadap parameter yang diamati interaksi kedua perlakuan saling tidak mendukung satu sama lainnya. Sehingga efeknya akar tanaman tidak saling merespon dan ini sesuai dengan pendapat Tjitrosoepomo, (1985) yang menyatakan bahwa pertumbuhan tanaman yang baik dapat tercapai bila faktor yang mempengaruhi pertumbuhan berimbang dan menguntungkan. Hal ini sesuai dengan pendapat Lingga (2004), menyatakan bahwa untuk responnya pupuk yang diberikan sangat ditentukan oleh berbagai faktor antara lain sifat genetis dari tanaman, iklim, tanah, dimana faktor-faktor tersebut tidak berdiri sendiri melainkan faktor yang satu berkaitan dengan faktor yang lainnya

\section{KESIMPULAN}

Pemberian limbah cair tahu belum mampu mempengaruhi pertumbuhan vegetative kelapa sawit dipembibitan awal, pemberian pupuk NPKMg dapat mempengaruhi tinggi tanaman dan luas daun tanaman kelapa sawit di pembibitan awal dan Interaksi antara pemberian limbah cair tahu dan pupuk NPKMg belum mampu mempengaruhi pertumbuhan vegetatif kelapa sawit di pembibitan awal. Pada penelitian ini perlakuan yang terbaik $\mathrm{P}_{2} \mathrm{~L}_{2}$.

\section{DAFTAR PUSTAKA}

Anggraini, S., Aji, S., dan Sitorus B. 2018. Pengaruh pemberian limbah cair tahu dan interval waktu terhadap pertumbuhan tanaman bibit kelapa sawit (Elaeis guineensis Jacq.) di pre nursery.

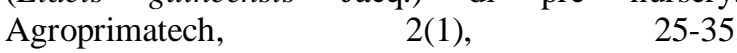
http://jurnal.unprimdn.ac.id/index.php/Agroprimatec h/article/view/773.

Chan, F., dan Tobing, E. L. 1982. Pemupukan bibit kelapa sawit. Pedoman Teknis. Buletin Pusat Penelitian Perkebunan Marihat, Pematang Siantar, Sumut.

Dartius. 1995. Fisiologi tanaman. USU, Medan.

Fahlei, R., Rahayu, E., dan Kautsar, V. 2017. Pengaruh pemberian air kelapa dan limbah cair ampas tahu pada tanah regosol terhadap pertumbuhan bibit kelapa sawit di pre nursery. Jurnal Agromast, (2(1), p.13.http://36.82.106.238:8885/jurnal/index.php/JAI /article/view/845.

Lakitan, B. 2004. Dasar-dasar fisiologi tumbuhan. Raja Grafindo Persada. Jakarta

Lingga. 1991. Aneka jenis tanam. Penebar Swadaya. Jakarta.

Lubis, A.U. 1992. Kelapa sawit (Elaeis guineensis Jacq) di Indonesia. Balai Penelitian Marihat. Sumatera Utara. Hal. 1-393.

Mangoensoekarjo, S. 2007. Manajemen tanah dan pemupukan budidaya perkebunan. Gadjah Mada Universty Press, Yogyakarta. Hal. 1-385. 
Musnamar.2006. Dosis Pupuk Kandang Untuk Tanaman Semusim.CV. Simelex Argo Media Pustaka. Depok Estate.

PPKS, 2001. Budidaya Kelapa Sawit. Pusat Penelitian Kelapa Sawit. Medan.

Purnomo, A. R., Kristalisasi, E. N., dan Firmansyah, E. 2017. Pengaruh dosis dan interval waktu penyiraman limbah cair pabrik tahu terhadap pertumbuhan bibit kelapa sawit (Elaeis guineensis Jacq.) di pre nursery. Jurnal Agromast, 2(2), p.8. http://36.82.106.238:8885/jurnal/index.php/JAI/arti cle/view/381.

Sastrosayono, S. 2008. Budidaya kelapa sawit. AgroMedia Pustaka. Jakarta

Setyati H. S. 2008. Pengantar agronomi. Gramedia Pustaka Utama. Jakarta,

Sumpena. 2001. Aneka jenis pupuk dan penggunaannya. Penebar Swadaya. Jakarta

Sutejo, M. 2002. Pupuk dan cara pemupukan. Rineka Cipta, Jakarta.

Suwardjono. 2003. Penerapan pertanian organik. Khusus: Yogyakarta.

Syarief, S. 2003. Kesuburan dan pemupukan tanah pertanian. Pustaka Buana. Jakarta

Tjitrosoepomo, G. 1985. Morfologi tumbuhan. Gajah Mada University Press. Yogyakarta.

Triharso. 1994. Dasar-dasar perlindungan pupuk pada tanaman. UGM, Yogyakarta.

Tusner, R. U., dan Gilbanks, R. A. 1972. Oil palm culbuation and manajemen, Malaysia. 